\title{
Prevalence of Heat-Related Illnesses among Outdoor Workplaces Workers in Hot and Dry Areas of Iran
}

\author{
Milad Derakhshanjazari ${ }^{1}$, Ali Jangjou ${ }^{2}$, Roohollah Bagherzadeh ${ }^{3}$, Mohammad Reza \\ Monazzam $^{4}$, Zahra Zamanian ${ }^{5 *}$ \\ ${ }^{1}$ Department of Occupational Health Engineering, School of Health, Shiraz University of Medical Sciences, Shiraz, Iran \\ ${ }^{2}$ Emergency Medicine Department, Shiraz University of Medical Sciences, Shiraz, Iran \\ ${ }^{3}$ Department of Textile Engineering, Advanced Textile Materials and Technology Research Institute (ATMT), Amirkabir University \\ of Technology, Tehran, Iran \\ ${ }^{4}$ Department of Occupational Health Engineering, Tehran University of Medical Sciences, Tehran, Iran \\ ${ }^{5}$ Department of Occupational Health Engineering, School of Health, Shiraz University of Medical Sciences, Shiraz, Iran
}

\begin{abstract}
The risk of heat-related illnesses (HRI) is very high in outdoor workers. Given that there are a large number of outdoor workers in areas of Iran and there is no comprehensive information on HRI among these workers in the risky workplace. Aim of the study is prevalence of HRI among outdoor workplaces workers in hot and dry areas of Iran. This cross-sectional study carried out among 1800 that randomly selected from outdoor workplaces workers in hot and dry cities of Iran in 2019. Data was collected by researcher-made questionnaire containing questions about information about the participants' demography and lifestyle; behavior modification during heat; knowledge about HRI; health status of the workplace; type of HRI symptoms in the Sumer 2019; job properties; and individual factors. Then, data analysis was performed using SPSS software version $19.76 .2 \%$ of the participants reported experiencing one or more HRI symptoms that $36 \%$ of them were related to headache. HRI is highest prevalence in agricultural workers (37\%). HRI symptom are significantly associated with age, work experience, type of working clothes, and ratio of rest/work ( $<<0.001)$. Results showed that reducing rest time and water consumption increased the prevalence of HRI $(\mathrm{p}<0.001)$. Prevalence of HRI is very high in among outdoor workplace workers in hot and dry areas of Iran, especially agriculture workers. Headache is most prevalence in the workers. Finally, consideration of working clothes, water consumption, and ratio of rest/work have an important role in reducing of HRI.
\end{abstract}

Keywords: Heat-related illnesses, Outdoor, Workers, Hot and dry

\section{Introduction}

Heat stress as a physical agent or hazard is influenced by environmental and individual factors (ie, air temperature, humidity, air movement, thermal radiation), the metabolic heat generated by human activity, and clothing type $(1,2)$. This adverse agent has many effects at outdoor and indoor workplaces such as agriculture, construction workers, ranchers, bakeries, glass industrials, smelters $(3,4)$. Excessive exposure to heat can cause physiological (5), and psychological effects (6), heat-related illnesses (HRI) symptoms such as heat exhaustion, heat stroke, headache, vertigo, and vomiting (7), kidney disease, syncope (8), and heart disorder (9), and can also increase occupational accident risk (10). Heat-related illness in outdoor workers are higher than indoor workers, because of both environmental and occupational exposure to heat $(11,12)$. In addition, global average dry temperature has been increasing, the forecast for a rise of 1.8 to 4 degree Celsius by 2100 (13), For outdoor workers, sun radiations and climatic conditions (e.g. low air movement, low humidity levels and high dry temperature) can cause heat stress. Numerous studies have reported the prevalence of HRI in outdoor workplaces workers. In Australia, reports showed that there were 485 cases of HRI in the 11 years from 1997 to 2007 (14). Also, 480 cases of heatstroke occurred in the United States in the 11 years from
1995 to 2005 (15). In Japan, 389 deaths occurred from 19892012 due to heat shocks (16). The reports indicate the importance of heat stress in the workplace.

Iran lies in western Asia. The population now estimated at 80.0 million. The area coverage of different types of climate in Iran is $35.5 \%$ hyper-arid, $29.2 \%$ arid, $20.1 \%$ semi-arid, $5 \%$ Mediterranean and $10 \%$ wet. Thus more than 82 percent of Iran's territory is located in the arid and semi-arid zone of the world (17). There are 14 million workers in Iran, about 8.5 million of whom work in outdoor workplaces. $30 \%$ of these workers work in 9 cities of Iran including Isfahan, Kerman, Sabzevar, Zahedan, Semnan, Kashan, Yazd, Zabol and Dezful that these cities are located hot and dry areas of Iran $(18,19)$. According to meteorological reports, the average dry air temperature and relative humidity over a period of 40 years in summer are about 30.2 Celsius degrees and 24 percent, respectively. Also, the radiation temperature in these areas is about 40 Celsius degrees (20). Given that there are a large number of outdoor workers in these areas of Iran and there is no comprehensive information on HRI among these workers in the risky workplace. Aim of the study is prevalence of heatrelated illnesses among outdoor workplaces workers in hot and dry areas of Iran.

Corresponding author: Zahra Zamanian, Department of Occupational Health Engineering, School of Health, Shiraz University of Medical Sciences, Shiraz, Iran. Koy-e-Zahra Street, PO Box: 71645-11, E-mail: zzamamian@yahoo.com. 


\section{Method and materials}

This cross-sectional study carried out to investigate the prevalence of HRI among outdoor workplaces workers in hot and dry areas of Iran in Sumer 2019. Isfahan, Kerman, Sabzevar, Zahedan, Semnan, Kashan, Yazd, Zabol and Dezful are cities in Iran. Studied workers were selected equally from each of cities using a random number table.

\subsection{Participants}

1800 male workers with at least one year of work experience in outdoor workplaces workers participated from studied cities. Participates haven't history of disease. 200 participants were selected from each city. Finally, 50 participants were selected from each of the four jobs including construction workers, agricultural workers, ranchers, workers in brick industries. In cases where the workers of a workplace refused to participate in the study or quitted their work during the data collection period, the workplace was excluded from the study and was replaced by another one.

\subsection{Data collection tools and quality control}

Data was collected by researcher-made questionnaire including information about the workers' demography; behavior during heat stress; knowledge about heat-related illnesses; occupational safety and health status of the workplace; type of HRI; job properties; and individual factors. The validity of the questions was confirmed by 30 occupational health and safety experts. For this purpose, questionnaires were sent to experts by e-mail and they gave us their feedback regarding the necessary modifications. The questionnaires were completed through interview by occupational health and safety experts. The data collection took three Months. Confidentiality was maintained and informed consent was obtained. The workers were told that the collected data was just for the aim of conducting a scientific study and they could discontinue participation in the study whenever they wished. During training of data collectors and supervisors, issues such as the data collection instrument, field methods, inclusionexclusion criteria and recordkeeping we emphasized. The researchers coordinated the interview process, and spotchecked and reviewed the completed questionnaires on a daily basis to ensure the completeness and consistency of the data collected. The interview questionnaire was pre-tested on 20 respondents in order to identify potential problem areas, unanticipated interpretations and cultural objections to any of the questions. Based on the pre-test results, the questionnaire was adjusted contextually.

\subsection{Data analysis}

Data was analyzed using SPSS software version 19. Descriptive statistics were reported for each variable. The normality of each variable was then tested using KolmogorovSmirnov test with the error rate of $\geq 0.05$. Chi-square and Pearson tests were used to determine factors associated with HRI. The odds ratio (OR) was also presented with a $95 \%$ confidence interval (CI) for significant variables. For multiplecomparison, Bonferroni correction was conducted by dividing the original $\alpha$-value by the number of analyses on the dependent variable.

\section{Results}

Table 1 shows the demographic and job characteristics of the outdoor workplace workers in hot and dry areas of Iran. The mean and standard deviation for age, work experience, and body mass index was $40.8 \pm 20.9,8.3 \pm 7.1,25.2 \pm 7.5$ and years, respectively. The mean and standard deviation for weekly working hours was $57 \pm 2.4$ hours, and $76.2 \%$ of the studied workers have experienced at least one of HRI.

Table 1: Socio-demographic characteristics of selected workers $(\mathrm{N}=1800)$

\begin{tabular}{|c|c|c|}
\hline \multicolumn{2}{|l|}{ Variables } & $\begin{array}{l}\text { Frequency } \\
(\%)\end{array}$ \\
\hline \multirow{4}{*}{ Age (Years) } & $\leq 20$ & $225(12.5)$ \\
\hline & $21-40$ & $755(41.9)$ \\
\hline & $41-60$ & $406(22.6)$ \\
\hline & $60<$ & $414(23.0)$ \\
\hline \multirow{2}{*}{ Marital status } & Married & $1194(66.3)$ \\
\hline & Single & $609(33.8)$ \\
\hline \multirow{3}{*}{ Education level } & Primary education & $1156(64.2)$ \\
\hline & Secondary education & $416(23.1)$ \\
\hline & Associate degree & $228(12.7)$ \\
\hline \multirow{4}{*}{$\begin{array}{l}\text { Work experience } \\
\text { (Years) }\end{array}$} & $1-4$ & $640(35.6)$ \\
\hline & $5-9$ & $457(25.4)$ \\
\hline & $10-14$ & $470(26.1)$ \\
\hline & $\geq 15$ & $233(12.9)$ \\
\hline \multirow{2}{*}{ Insurance status } & Yes & $813(45.2)$ \\
\hline & No & $987(54.8)$ \\
\hline \multirow{2}{*}{ Health training } & Yes & $589(32.7)$ \\
\hline & No & $1211(67.3)$ \\
\hline \multirow{2}{*}{ Employment status } & Seasonal & $1031(57.3)$ \\
\hline & Permanent & $769(42.7)$ \\
\hline \multirow{2}{*}{ Health inspection } & Yes & $951(52.8)$ \\
\hline & No & $849(47.2)$ \\
\hline \multirow{4}{*}{ Type of clothe } & Cotton & $880(48.9)$ \\
\hline & Polyester & $312(17.3)$ \\
\hline & Cotton and polyester & $350(19.4)$ \\
\hline & Other & $258(14.3)$ \\
\hline \multirow{2}{*}{ Water consumption } & Yes & $1449(80.5)$ \\
\hline & No & $351(19.5)$ \\
\hline \multirow{3}{*}{$\begin{array}{l}\text { Ratio of rest/work } \\
\text {; each hour }\end{array}$} & $75 \%$ work $+25 \%$ rest & $257(14.3)$ \\
\hline & $50 \%$ work $+50 \%$ rest & $341(18.9)$ \\
\hline & $25 \%$ work $+75 \%$ rest & $1202(66.8)$ \\
\hline \multirow{2}{*}{ Alcohol consumption } & Yes & $81(4.5)$ \\
\hline & No & $1719(95.5)$ \\
\hline \multirow{4}{*}{ BMI } & $<18.5$ & $117(6.5)$ \\
\hline & $18.5-24.9$ & $753(41.8)$ \\
\hline & $25-29.9$ & $584(32.4)$ \\
\hline & $\geq 30$ & $346(19.2)$ \\
\hline \multirow{2}{*}{ Cigarette smoking } & Yes & $459(25.5)$ \\
\hline & No & $1341(74.5)$ \\
\hline \multirow{2}{*}{$\begin{array}{l}\text { Experience of heat- } \\
\text { related illnesses }\end{array}$} & Yes & $1373(76.2)$ \\
\hline & No & $427(23.7)$ \\
\hline
\end{tabular}

Table 2 shows Frequency of Type of HRI in each of studied outdoor workplace workers. The highest prevalence of HRI is vertigo in construction workers (55 workers). The highest prevalence of HRI is headache in farmer workers (253 workers). The highest prevalence of HRI is headache in rancher workers (65 workers). The highest prevalence of HRI is headache in brick industries workers (65 workers). In this study, the prevalence rate of HRI was $76.2 \%$ in outdoor workplace workers in hot and dry of Iran. The highest prevalence HRI is headache in all of studied workers $(36 \%)$. The prevalence of HRI is different among studied outdoor workplace workers, as shown in Figure 2. Results of this study showed that HRI is highest prevalence in agricultural workers $(37 \%)$. 
Table 2: Frequency of Type of heat-related illnesses in each of studied outdoor workplace workers

\begin{tabular}{|c|c|c|c|c|c|}
\hline \multirow{2}{*}{$\begin{array}{l}\text { Type of heat-related } \\
\text { illnesses }\end{array}$} & \multicolumn{4}{|c|}{ Frequency and (percent) of illness in each of jobs } & \multirow[b]{2}{*}{ Total $(\%)$} \\
\hline & $\begin{array}{l}\text { Construction } \\
\text { workers }(\%)\end{array}$ & $\begin{array}{l}\text { Agricultural } \\
\text { workers }(\%)\end{array}$ & Ranchers $(\%)$ & $\begin{array}{l}\text { Brick industries } \\
(\%)\end{array}$ & \\
\hline Syncope & $4(0.29)$ & $19(1.39)$ & $0(0.00)$ & $7(0.51)$ & $30(2.2)$ \\
\hline Seizures & $4(0.29)$ & $8(0.59)$ & $1(0.07)$ & $4(0.29)$ & $17(1.2)$ \\
\hline Heat stroke & $23(1.68)$ & $31(2.27)$ & $7(0.51)$ & $42(3.07)$ & $103(7.5)$ \\
\hline Heat cramps & $22(1.61)$ & $41(3.00)$ & $23(1.68)$ & $39(2.85)$ & $125(9.1)$ \\
\hline Heat exhaustion & $48(3.51)$ & $41(3.00)$ & $21(1.54)$ & $54(3.95)$ & $164(11.9)$ \\
\hline Vomiting & $24(1.76)$ & $16(1.17)$ & $51(3.73)$ & $41(3.00)$ & $132(9.6)$ \\
\hline Headache & $47(3.44)$ & $253(18.51)$ & $65(4.75)$ & $132(9.66)$ & $497(36.2)$ \\
\hline Vertigo & $55(4.02)$ & $95(6.95)$ & $48(3.51)$ & $107(7.83)$ & $305(22.2)$ \\
\hline Total $(\%)$ & $227(16.61)$ & $504(36.87)$ & $216(15.80)$ & $426(31.16)$ & $1373(100)$ \\
\hline
\end{tabular}

Table 3 presents the relationship between HRI and demographic and job characteristics in studied outdoor workplace workers. As can be seen, most HRI are significantly associated with age, work experience, type of used clothes, and ratio of rest/work $(\mathrm{p}<0.001)$.

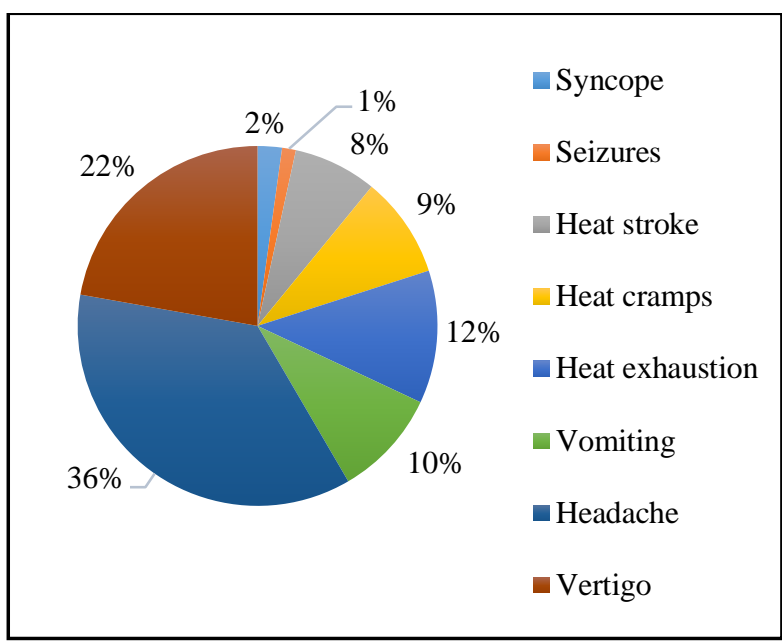

Figure 1: Prevalence of heat-related illnesses among studied outdoor workplace workers

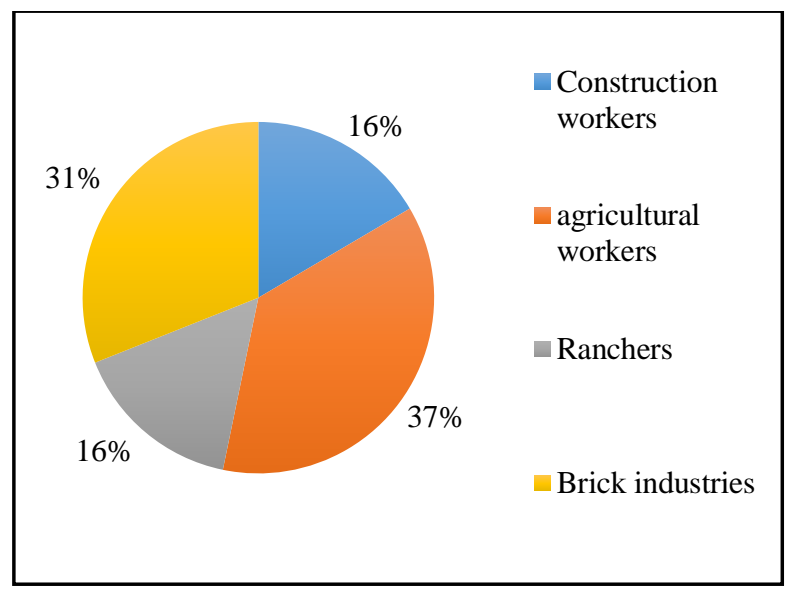

Figure 2: Prevalence of heat-related illnesses according to type of outdoor workplace

According to table 3 , results showed that reducing rest time increased the prevalence of HRI $(p<0.001)$. The prevalence of heat-related illness is lower in workers that use cotton working clothes $(p<0.001)$. Increasing body mass index increases heat stroke, heat cramps, heat exhaustion, and vertigo in studied outdoor workplaces workers $(\mathrm{p}<0.001)$. Table 4 presents odds ratios for relationship between HRI and other sociodemographic and job characteristics that have two-state in studied outdoor workplace workers. According to table 4, In this study, the rate of HRI including heat exhaustion among married workers was 2 times higher than those among single ones [OR=1.94, $95 \% \mathrm{CI}(1.17-2.73)]$. The prevalence of HRI had an inverse association with health training programs so that workers attending health training programs have experienced a decrease in heat-related illness compared with other workers that showed in table 4. Moreover, Seasonal workers experienced more HRI compared with permanent workers that it was more than 2 times higher than permanent workers. As can be seen in table 4, the HRI is the highest prevalence in workers who don't drink water. Results of this study showed that there is no relationship between HRI and alcohol consumption.

\section{Discussion}

Results of this study showed that prevalence of HRI was \%75.2 among outdoor workplace workers in hot and dry areas of Iran. In the study, heat-related illness is highest prevalence in agricultural workers $(37 \%)$. Headache (36\%), vertigo (22 $\%)$ and vomiting (10\%) have been the most prevalent HRI among outdoor workplace worker, respectively. The prevalence of HRI among studied workers was significantly associated with age, work experience, type of working clothes, water consumption, ratio of rest/work, and employment status in studied workers. In study of Jeffrey W. Bethel and et al. (2014), one of the key findings from this study is that nearly $30 \%$ of participants reported experiencing two or more HRI symptoms in Oregon (21). Mirabelli et al. (2010) collected cross-sectional survey data from 300 Latino men $(n=285)$ and women $(n=15)$ in 2009 and found that $40 \%$ of those working in extreme heat experienced symptoms of HRI North Carolina.(22). But, in our study, $76.2 \%$ of the studied workers participants reported experiencing one or more HRI symptoms. The difference in the prevalence rate of HRI can be due to factors such as differences in demographic characteristics of workers, different sample size, and research method. The most important reason for this prevalence difference can be working in hot and dry area of Iran that workers are exposed to high temperature and low humidity. Many studies have shown that the prevalence of heat-related illness in agricultural workers is higher than other outdoor workplace workers (23-25). In this study, we also reached this result. The probable reason is that agricultural workers have more exposure to air temperature, low humidity, and radiant heat. Also, the metabolic heat generated by human physical activity is higher in agricultural workers which caused Increases body temperature 
Table 3: The association between overall heat-related illnesses and demographic characteristics of the outdoor workplaces workers

\begin{tabular}{|c|c|c|c|c|c|c|c|c|c|}
\hline \multirow{2}{*}{\multicolumn{2}{|c|}{ Variables }} & \multicolumn{8}{|c|}{ Type of heat-related illnesses } \\
\hline & & \multirow{2}{*}{$\begin{array}{l}\text { Syncope } \\
\mathrm{N}(\%) \\
\end{array}$} & \multirow{2}{*}{$\begin{array}{l}\text { Seizures } \\
\mathrm{N}(\%) \\
4(23.5)\end{array}$} & \multirow{2}{*}{$\begin{array}{l}\begin{array}{l}\text { Heat } \\
\text { stroke }\end{array} \\
\mathrm{N}(\%) \\
16(15.5)\end{array}$} & \multirow{2}{*}{$\begin{array}{l}\begin{array}{l}\text { Heat } \\
\text { cramps }\end{array} \\
\mathrm{N}(\%) \\
6(4.8)\end{array}$} & \multirow{2}{*}{$\begin{array}{l}\begin{array}{l}\text { Heat } \\
\text { exhaustion }\end{array} \\
\mathrm{N}(\%) \\
22(13.4)\end{array}$} & \multirow{2}{*}{$\begin{array}{l}\text { Vomiting } \\
\mathrm{N}(\%) \\
29(22.0)\end{array}$} & \multirow{2}{*}{$\begin{array}{l}\text { Headache } \\
\mathrm{N}(\%) \\
41(8.2)\end{array}$} & \multirow{2}{*}{$\begin{array}{l}\text { Vertigo } \\
\mathrm{N}(\%) \\
56(18.4)\end{array}$} \\
\hline \multirow{5}{*}{ Age (Years) } & $\leq 20$ & & & & & & & & \\
\hline & $21-40$ & $1(3.3)$ & $4(23.5)$ & $9(8.7)$ & $27(21.6)$ & $32(19.5)$ & $27(20.5)$ & $36(7.2)$ & 49 (16.1) \\
\hline & $41-60$ & $19(63.3)$ & $2(11.7)$ & $41(39.8)$ & $59(47.2)$ & $31(18.9)$ & $34(25.8)$ & $226(45.5)$ & 137(44.9) \\
\hline & $60<$ & $10(33.3)$ & $7(41.3)$ & 37 (35.9) & $33(26.4)$ & $79(48.2)$ & $42(31.8)$ & $194(39.0)$ & $63(20.7)$ \\
\hline & p-value & $<0.001$ & $>0.05$ & $<0.001$ & $<0.001$ & $<0.001$ & $>0.05$ & $<0.001$ & $>0.05$ \\
\hline \multirow{4}{*}{$\begin{array}{l}\text { Education } \\
\text { level }\end{array}$} & $\begin{array}{l}\text { Primary } \\
\text { education }\end{array}$ & 17 (56.7) & $7(41.3)$ & $34(34)$ & $69(55.2)$ & $57(34.8)$ & $46(34.8)$ & $112(22.5)$ & 76 (24.9) \\
\hline & $\begin{array}{l}\text { Secondary } \\
\text { education }\end{array}$ & $9(30)$ & $6(35.3)$ & $59(57.3)$ & $21(16.8)$ & $43(26.2)$ & 47 (35.6) & $204(41.0)$ & $145(47.5)$ \\
\hline & $\begin{array}{l}\text { Associate } \\
\text { degree }\end{array}$ & $4(13.3)$ & $4(23.5)$ & $10(9.7)$ & $13(10.4)$ & $64(39.0)$ & $39(29.5)$ & $181(36.4)$ & $84(27.5)$ \\
\hline & p-value & $<0.001$ & $>0.05$ & $>0.05$ & $<0.001$ & $>0.05$ & $>0.05$ & $<0.001$ & $>0.05$ \\
\hline \multirow{5}{*}{$\begin{array}{l}\text { Work } \\
\text { experience } \\
\text { (Years) }\end{array}$} & $1-4$ & $16(53.3)$ & $9(53)$ & $67(65)$ & $30(24)$ & $39(23.8)$ & $56(42.4)$ & $234(47.1)$ & $132(43.3)$ \\
\hline & $5-9$ & $5(16.7)$ & $3(17.7)$ & $30(29.1)$ & $33(26.4)$ & $53(32.3)$ & $32(24.2)$ & $103(20.7)$ & $53(17.4)$ \\
\hline & $10-14$ & $5(16.7)$ & $4(23.5)$ & $3(3)$ & $37(29.6)$ & $30(18.3)$ & $27(20.5)$ & $62(12.5)$ & $69(22.6)$ \\
\hline & $\geq 15$ & $4(13.3)$ & $1(0.6)$ & $3(3)$ & $25(20)$ & $42(25.6)$ & $17(12.9)$ & $98(19.7)$ & $51(16.7)$ \\
\hline & p-value & $<0.001$ & $<0.001$ & $<0.001$ & $<0.001$ & $<0.001$ & $<0.001$ & $<0.001$ & $<0.001$ \\
\hline \multirow{5}{*}{$\begin{array}{l}\text { Type of } \\
\text { working } \\
\text { clothes }\end{array}$} & Cotton & $0(0.0)$ & $3(17.7)$ & $19(18.4)$ & $5(4)$ & $53(32.3)$ & $31(23.5)$ & $56(11.3)$ & 44 (14.4) \\
\hline & Polyester & $9(30)$ & $5(29.4)$ & $21(20.4)$ & $33(26.4)$ & $73(44.5)$ & $35(26.5)$ & $194(39.0)$ & $89(29.2)$ \\
\hline & $\begin{array}{l}\text { Cotton and } \\
\text { polyester }\end{array}$ & $11(36.7)$ & $6(35.3)$ & $23(22.3)$ & $29(23.2)$ & $21(12.8)$ & $41(31.1)$ & $176(35.4)$ & $64(21.0)$ \\
\hline & Other & $12(40)$ & $3(17.7)$ & $40(38.8)$ & 62 (49.6) & 17 (10.4) & 25 (18.9) & 71 (14.3) & $108(35.4)$ \\
\hline & p-value & $<0.001$ & $>0.05$ & $<0.001$ & $<0.001$ & $<0.001$ & $>0.05$ & $<0.001$ & $<0.001$ \\
\hline \multirow{4}{*}{$\begin{array}{l}\text { Ratio of } \\
\text { rest/work }\end{array}$} & $\begin{array}{l}75 \% \text { work + } \\
25 \% \text { rest }\end{array}$ & $28(93.3)$ & $11(64.7)$ & $41(39.8)$ & 103(82.4) & $98(59.8)$ & $55(41.7)$ & $312(62.8)$ & 201(65.9) \\
\hline & $\begin{array}{l}50 \% \text { work + } \\
50 \% \text { rest }\end{array}$ & $1(3.3)$ & $2(11.8)$ & 45 (43.7) & $3(2.4)$ & $45(27.4)$ & $57(43.2)$ & 83 (16.7) & 57 (18.7) \\
\hline & $\begin{array}{l}25 \% \text { work + } \\
75 \% \text { rest }\end{array}$ & $1(3.3)$ & $3(17.7)$ & $17(16.5)$ & $19(15.2)$ & $21(12.8)$ & $20(15.2)$ & $102(20.5)$ & 47 (15.4) \\
\hline & p-value & $<0.001$ & $<0.001$ & $<0.001$ & $<0.001$ & $<0.001$ & $<0.001$ & $<0.001$ & $<0.001$ \\
\hline \multirow{5}{*}{ BMI } & $<18.5$ & $10(33.3)$ & $3(17.7)$ & $6(5.8)$ & $21(16.8)$ & $26(15.9)$ & $32(24.2)$ & $111(22.3)$ & $53(17.4)$ \\
\hline & $18.5-24.9$ & $3(10)$ & $2(11.8)$ & $3(2.9)$ & 17 (13.6) & $27(16.5)$ & $31(23.5)$ & $109(21.9)$ & $61(20.0)$ \\
\hline & $25-29.9$ & $3(10)$ & $4(23.5)$ & $39(37.9)$ & $36(28.8)$ & $12(7.3)$ & $46(34.8)$ & $173(34.8)$ & $67(22.0)$ \\
\hline & $\geq 30$ & $14(46.7)$ & $9(53)$ & $55(53.4)$ & $51(40.8)$ & $99(60.4)$ & $23(17.4)$ & $104(20.9)$ & 124(40.7) \\
\hline & $\mathrm{p}$-value & $>0.05$ & $>0.05$ & $<0.001$ & $<0.001$ & $<0.001$ & $>0.05$ & $>0.05$ & $<0.001$ \\
\hline
\end{tabular}

*Statistically significant at $\mathrm{p}<0.05$

Table 4: Odds ratios of exposure to heat-related illnesses based on two-state variables

\begin{tabular}{|c|c|c|c|c|c|c|c|c|}
\hline \multirow[b]{2}{*}{ Variables } & \multicolumn{8}{|c|}{ OR ( \%95 CI) } \\
\hline & Syncope & Seizures & $\begin{array}{l}\text { Heat } \\
\text { stroke }\end{array}$ & $\begin{array}{l}\text { Heat } \\
\text { cramps }\end{array}$ & $\begin{array}{l}\text { Heat } \\
\text { exhaustion }\end{array}$ & Vomiting & Headache & Vertigo \\
\hline $\begin{array}{l}\text { Marital status } \\
\text { (Married, Single) }\end{array}$ & $\begin{array}{l}1.05(0.55- \\
1.7)\end{array}$ & $\begin{array}{l}0.91(0.23- \\
1.55)\end{array}$ & $\begin{array}{l}1.33(1.17- \\
1.6)^{*} \\
\end{array}$ & $\begin{array}{l}3.1(1.8- \\
4.25)^{*}\end{array}$ & $\begin{array}{l}1.94(1.17- \\
2.73)^{*}\end{array}$ & $\begin{array}{l}1.73(1.09- \\
2.64)^{*}\end{array}$ & $\begin{array}{l}3.23(1.97- \\
4.58)^{*}\end{array}$ & $\begin{array}{l}1.56(0.79- \\
2.27)\end{array}$ \\
\hline $\begin{array}{l}\text { Insurance status } \\
\text { (Yes, No) }\end{array}$ & $\begin{array}{l}0.88 \\
(0.52-1.31)\end{array}$ & $\begin{array}{l}1.08 \\
(0.71-1.57)\end{array}$ & $\begin{array}{l}0.87 \\
(0.51- \\
1.29) \\
\end{array}$ & $\begin{array}{l}1.79 \\
(0.91- \\
2.22) \\
\end{array}$ & $\begin{array}{l}1.62 \\
(1.09-3.10)^{*}\end{array}$ & $\begin{array}{l}1.62 \\
(0.81-3.00)\end{array}$ & $\begin{array}{l}1.67 \\
(0.85-2.96)\end{array}$ & $\begin{array}{l}1.18 \\
(0.88-1.94)\end{array}$ \\
\hline $\begin{array}{l}\text { Health training } \\
\text { (Yes, No) }\end{array}$ & $\begin{array}{l}0.41 \\
(0.24-0.51)^{*}\end{array}$ & $\begin{array}{l}0.36 \\
(0.17- \\
0.59)^{*} \\
\end{array}$ & $\begin{array}{l}0.24 \\
(0.06- \\
0.44)^{*} \\
\end{array}$ & $\begin{array}{l}0.41 \\
(0.25- \\
0.74)^{*} \\
\end{array}$ & $\begin{array}{l}0.23 \\
(0.13-0.36)^{*}\end{array}$ & $\begin{array}{l}0.52 \\
(0.37-0.71)^{*}\end{array}$ & $\begin{array}{l}0.28 \\
(0.17-0.41)^{*}\end{array}$ & $\begin{array}{l}1.21 \\
(0.19-2.34)\end{array}$ \\
\hline $\begin{array}{l}\text { Employment status } \\
\text { (Seasonal, } \\
\text { Permanent) }\end{array}$ & $\begin{array}{l}2.71 \\
(1.83-3.73)^{*}\end{array}$ & $\begin{array}{l}2.21 \\
(1.81- \\
2.26)^{*} \\
\end{array}$ & $\begin{array}{l}2.52 \\
(1.6- \\
3.74)^{*} \\
\end{array}$ & $\begin{array}{l}2.33 \\
(1.70- \\
3.15)^{*} \\
\end{array}$ & $\begin{array}{l}4.03 \\
(2.88-5.84)^{*}\end{array}$ & $\begin{array}{l}7.71 \\
(5.12-11.7)^{*}\end{array}$ & $\begin{array}{l}5.05 \\
(3.12-7.06)^{*}\end{array}$ & $\begin{array}{l}2.71 \\
(1.5-3.36)^{*}\end{array}$ \\
\hline $\begin{array}{l}\text { Health inspection } \\
\text { (Yes, No) }\end{array}$ & $\begin{array}{l}1.81 \\
(1.07-3.22)^{*}\end{array}$ & $\begin{array}{l}1.64 \\
(0.77-3.57)\end{array}$ & $\begin{array}{l}1.12 \\
(0.58- \\
1.69) \\
\end{array}$ & $\begin{array}{l}0.74 \\
(0.30- \\
1.30) \\
\end{array}$ & $\begin{array}{l}1.77 \\
(1.05-3.03)^{*}\end{array}$ & $\begin{array}{l}2.33 \\
(1.25-4.86)^{*}\end{array}$ & $\begin{array}{l}0.97 \\
(0.49-2.01)\end{array}$ & $\begin{array}{l}1.18 \\
(0.36-1.87)\end{array}$ \\
\hline $\begin{array}{l}\text { Water consumption } \\
\text { (Yes, No) }\end{array}$ & $\begin{array}{l}0.22 \\
(0.11-0.29)^{*}\end{array}$ & $\begin{array}{l}0.32 \\
(0.20- \\
0.41)^{*} \\
\end{array}$ & $\begin{array}{l}0.11 \\
(0.06- \\
0.14)^{*} \\
\end{array}$ & $\begin{array}{l}0.17 \\
(0.12- \\
0.24)^{*} \\
\end{array}$ & $\begin{array}{l}0.09 \\
(0.06-0.13)^{*}\end{array}$ & $\begin{array}{l}0.42 \\
(0.22-0.60)^{*}\end{array}$ & $\begin{array}{l}0.30 \\
(0.23-0.45)^{*}\end{array}$ & $\begin{array}{l}0.10 \\
(0.02- \\
0.19)^{*} \\
\end{array}$ \\
\hline $\begin{array}{l}\text { alcohol consumption } \\
\text { (Yes, No) }\end{array}$ & $\begin{array}{l}1.31 \\
(0.54-2.18)\end{array}$ & $\begin{array}{l}1.02 \\
(0.69-1.90)\end{array}$ & $\begin{array}{l}1.33 \\
(0.73- \\
2.36) \\
\end{array}$ & $\begin{array}{l}0.97 \\
(0.51- \\
1.55) \\
\end{array}$ & $\begin{array}{l}0.77 \\
(0.65-1.13)\end{array}$ & $\begin{array}{l}1.79 \\
(0.91-2.90)\end{array}$ & $\begin{array}{l}0.90 \\
(0.65-1.35)\end{array}$ & $\begin{array}{l}1.00 \\
(0.28-1.61)\end{array}$ \\
\hline $\begin{array}{l}\text { Cigarette smoking } \\
\text { (Yes, No) }\end{array}$ & $\begin{array}{l}1.25(0.89- \\
2.09)\end{array}$ & $\begin{array}{l}0.94 \\
(0.42-2.00)\end{array}$ & $\begin{array}{l}1.26 \\
(0.17- \\
2.27) \\
\end{array}$ & $\begin{array}{l}1.71 \\
(0.96- \\
2.90) \\
\end{array}$ & $\begin{array}{l}0.90 \\
(0.56-1.60)\end{array}$ & $\begin{array}{l}1.16 \\
(0.66-1.66)\end{array}$ & $\begin{array}{l}0.79 \\
(0.65-0.85)^{*}\end{array}$ & $\begin{array}{l}1.59 \\
(1.15- \\
2.02)^{*}\end{array}$ \\
\hline
\end{tabular}


In a study Jeffrey W. Bethel and et al , heavy sweating $(50 \%)$ and headache $(24 \%)$ were the most commonly reported symptoms (21). In our study, headache $(36 \%)$ is the highest prevalence of HRI symptoms among outdoor workplaces workers in hot and dry areas of Iranian. These different results are probably due to differences in the type of nutrition, working time, and physiological characteristics of workers. In a study by Roh Allahparvari and his colleagues in 2015, they researched four examples of workers' working clothes with low, medium, and high workload and their most important result was that working clothe with $100 \%$ cotton textile was recommended for low-hard workload, and working clothes with textile $69.8 \%$ polyester and $30.2 \%$ cotton for mediumhard workload was recommended for Iranian workers (26). It was also reported in our study that type of working clothes made of different textiles have effect on prevalence of HRI in outdoor workplace workers. Probably, clothing interferes with humans' ability to regulate the thermal balance with the environment and lose heat to the environment which has been confirmed in many studies $(27,28)$.

June T. Spector and et al. (2016) reported that risk factors for HRI symptoms in Washington crop workers, decreased age (and less work experience), piece rate pay, and longer distance to the toilet were associated with self-reported HRI symptoms (29). In the present study reported same results that less work experience and water consumption can caused increase prevalence of HRI. It is probably due to workers incompatibility with heat and severe dehydration in debilitated workers can lead to shock, coma and eventually death. In study of Kwasi Frimpong and et al showed that workers who more rest can work longer hours at higher temperatures. Results of this study that decreasing the rest-to-work ratio increases the prevalence of heat-related illness (30). This shows that the long-term presence of workers in the outdoor workplace is a seriously threatening to the prevalence of heat-related illness in hot and dry areas. There were some limitations in this study that should be taken into consideration when interpreting the results. In this study, age and alcohol consumption in studied workers could be intervening variables in proving the role of work experience in causing HRI, probably due to the lack of proper selection of samples in different age and alcohol consumption groups.

\section{Conclusion}

The results of this study showed that the prevalence of HRI is very high in among outdoor workplace workers in hot and dry areas of Iran. $76.2 \%$ of the outdoor workers reported experiencing one or more HRI symptoms that most prevalence of HRI is among agricultural workers. Also, headache is most prevalence in the outdoor workers. Type of working clothes, water consumption, Work experience, and ratio of rest/work have important role in heat-related illness. Considering the high prevalence of HRI among outdoor workplace workers and effective factors on HRI, more stringent occupational safety and health interventions are recommended in outdoor workplace workers.

\section{Acknowledgments}

We thank the author(s), studied outdoor workers and occupational health and safety experts for their consultation and cooperation. Also, we thank Mohammad Salehi, Amin Sheykhbabaei, Mehrab Derakhshan, Vahid poursoleyman, Sepideh Zare rafi, Hadi Asady, Vahid Kazemi Moghaddam, and Mohammad Reza Ariaeifar for their collaborate on data collection

\section{Funding}

The author(s) received financial support for the research, authorship, and/or publication of this article: This study as a Ph.D. degree thesis (code: 20825) was supported by Shiraz University of Medical Sciences.

\section{Ethical issue}

Authors are aware of, and comply with, best practice in publication ethics specifically with regard to authorship (avoidance of guest authorship), dual submission, manipulation of figures, competing interests and compliance with policies on research ethics. Authors adhere to publication requirements that submitted work is original and has not been published elsewhere in any language.

\section{Competing interests}

The authors declare that there is no conflict of interest that would prejudice the impartiality of this scientific work.

\section{Authors' contribution}

All authors of this study have a complete contribution for data collection, data analyses and manuscript writing.

\section{References}

.1 GOLBABAEI F, MONAZZAM M, HEMATJO R, HOSSEINI M, FAHANG-DEHGHAN SJIJoOH. The assessment of heat stress and heat strain in pardis petrochemical complex, Tehran, Iran. 2013;5(1):6-11.

.2 Asghari M, Nassiri P, Monazzam MR, Golbabaei F, Arabalibeik $\mathrm{H}$, Shamsipour A, et al. Weighting Criteria and Prioritizing of Heat stress indices in surface mining using a Delphi Technique and Fuzzy AHP-TOPSIS Method. 2017;15(1):1.

.3 Wang F, Gao C, Kuklane K, Holmér IJIh. Effects of various protective clothing and thermal environments on heat strain of unacclimated men: the PHS (predicted heat strain) model revisited. 2013:2012-0073

4 Braeckman L, Valcke M, Smits P, van Dijk F, Gehanno J-F, Pauncu EA, et al., editors. EMUTOM: a European module on undergraduate teaching in occupational medicine. 30th International congress on Occupational Health (ICOH 2012): Occupational health for all: from research to practice; 2012.

5 Holmer IJIh. Protective clothing in hot environments. 2006;44(3):404-13.

6 Gaoua N, Racinais S, Grantham J, El Massioui FJIJoH. Alterations in cognitive performance during passive hyperthermia are task dependent. 2011;27(1):1-9.

.7 Kovats RS, Hajat SJARPH. Heat stress and public health: a critical review. 2008;29:41-55.

.8 Tawatsupa B, Lim LL, Kjellstrom T, Seubsman S-a, Sleigh A, epidemiology TCSTJJo. Association between occupational heat stress and kidney disease among 37816 workers in the Thai Cohort Study (TCS) . 2012;22(3):251-60.

9 Donaldson GC, Keatinge WR, Saunders RDJIJoH. Cardiovascular responses to heat stress and their adverse consequences in healthy and vulnerable human populations. 2003;19(3):225-35.

10 Tawatsupa B, Lim L-Y, Kjellstrom T, Seubsman S-a, Sleigh A, action TCStcJGh. The association between overall health, psychological distress, and occupational heat stress among a large national cohort of 40,913 Thai workers. 2010;3(1):5034.

.11 Jay O, Kenny GPJAjoim. Heat exposure in the Canadian workplace. 2010;53(8):842-53.

12 Miller V, Bates GJJoOH, Australia S, Zealand N. Hydration of outdoor workers in north-west Australia. 2007;23(1):79.

13 Kjellstrom T, Holmer I, Lemke BJGha. Workplace heat stress, health and productivity-an increasing challenge for low and middle-income countries during climate change. 2009;2(1):2047.

14 Australia S. Occupational Health and Safety Statistics ReportNumber of Cases 2011. 2011.

15 Bonauto D, Anderson R, Rauser E, Burke BJAjoim. Occupational heat illness in Washington State, 1995-2005. 2007;50(12):940-50. 
.16 Horie SJJ. Prevention of heat stress disorders in the workplace. 2013;56(3):186-92.

.17 Amiri M, Eslamian SJJoES, Technology. Investigation of climate change in Iran. 2010;3(4):208-16.

.18 Nassiri P, Reza Monazzam M, Golbabaei F, Abbasinia M, Chavoshi M, Taheri F, et al. Exposure to heat stress in the workplace: A systematic review. 2018;15.(2)

.19 Hajizadeh R, Farhang Dehghan S, Mehri A, Jafari S, Golbabaei FJJoH. Effect of Heat Stress on Productivity Loss of Outdoor Workers: A Case Study in a Hot and Dry Climate. 2018;9(3):30213.

20 ZARE AH. STUDY OF HUMAN COMFORT BASED ON BIOCLIMATE INDEX IN WARM AND ARID REGIONS OF IRAN. 2013.

.21 Bethel JW, Harger RJIjoer, health p. Heat-related illness among Oregon farmworkers. 2014;11(9):9273-85.

.22 Mirabelli MC, Quandt SA, Crain R, Grzywacz JG, Robinson EN, Vallejos QM, et al. Symptoms of heat illness among Latino farm workers in North Carolina. 2010;39(5):468-71.

.23 Jackson LL, Rosenberg HRJJoa. Preventing heat-related illness among agricultural workers. 2010;15(3):200-15.

.24 Stoecklin-Marois M ,Hennessy-Burt T, Mitchell D, Schenker MJIh. Heat-related illness knowledge and practices among California hired farm workers in the MICASA study. 2013;51(1):47-55.

.25 Flocks J, Vi Thien Mac V, Runkle J, Tovar-Aguilar JA, Economos J, McCauley LAJJoa. Female farmworkers' perceptions of heatrelated illness and pregnancy health. 2013;18(4):350-8.

.26 Parvari RA, Aghaei HA, Dehghan H, Khademi A, Maracy MR, Dehghan SFJAoe, et al. The effect of fabric type of common iranian working clothes on the induced cardiac and physiological strain under heat stress. 2015;70(5):272-8.

.27 Brazaitis M, Kamandulis S, Skurvydas A, Daniusevičiūtė LJAE. The effect of two kinds of T-shirts on physiological and psychological thermal responses during exercise and recovery. 2010.51-46:(1)42;

.28 Qian X, Fan JJTAooh. Prediction of clothing thermal insulation and moisture vapour resistance of the clothed body walking in wind. 2006;50(8):833-42.

.29 Spector JT, Krenz J, Blank KNJJoa. Risk factors for heat-related illness in Washington crop workers. 2015;20(3):349-59.

.30 Frimpong K, Eddie Van Etten E, Oosthuzien J, Nunfam VFJijob. Heat exposure on farmers in northeast Ghana. 2017;61(3):397406. 